\title{
Race Has Always Mattered: An Intergeneration Look at Race, Space, Place, and Educational Experiences of Blacks
}

\author{
Denise G. Yull \\ Department of Human Development, College of Community and Public Affairs, Binghamton University, \\ Binghamton, NY 13902-6000, USA \\ Correspondence should be addressed to Denise G. Yull; dyull@binghamton.edu
}

Received 3 June 2014; Revised 2 September 2014; Accepted 10 September 2014; Published 1 October 2014

Academic Editor: David Neumann

Copyright (C) 2014 Denise G. Yull. This is an open access article distributed under the Creative Commons Attribution License, which permits unrestricted use, distribution, and reproduction in any medium, provided the original work is properly cited.

Within school settings race continues to be one of the most formidable obstacles for Black children in the United States (US) school system. This paper expands the discussions of race in education by exploring how the social links among race, space, and place provide a lens for understanding the persistence of racism in the educational experiences of Black children. This paper examines how differences in a rural versus urban geographical location influence a student's experience with race, racism, and racial identity across four generations of Black people in the context of school and community. Implications for research and practice are discussed.

\section{Introduction}

More than one hundred years after W.E.B. Du Bois made his famous declaration about the color line, Black children continue to be challenged by racism in their educational journey. This is evidenced by a number of researchers who have written about the racial gap in educational outcomes between Black and White students, which include differences in standardized test scores and high school graduation rates [1-9]. Research has shown that Black students are subjected to harsher discipline than White students, and are more likely to be placed in special education classes, thus limiting their educational potential (e.g., [10-13]).

This paper engages and builds on the critical discourse of race in education by exploring how the social links between race and geographical space provide a lens for understanding the persistence of racism in the educational experiences of Black children. The exploration of space examines the experiences of those living in a rural versus an urban location in one northern US state and what influences a Black student's experience with race, racism, and racial identity in the context of school and community. The voices of four generations of Black Americans provide an intergenerational perspective on race and racism in the school experience of Black people. The generational groups include: Elders/Silent generation (born during 1930-1949), Black Power/Baby Boomer Generation (born during 1950-1969), Generation X/Hip Hop (born during 1970-1987), and Generation Y/Millennial (born during 1988-1995).

In addition to filling a void in research on the educational experiences of Blacks in the northern part of the US within an intergenerational framework, this study challenges the notion of the one size fits all approach to educational policies and programs directed at Black children. The challenges faced by Black children today require the specifics of race and space to be acknowledged in their educational experiences. As O'Connor and colleagues [2] suggest, historically specific analyses of the educational realities of Blacks can help researchers unpack and explain the variegated experiences of Black students operating in different spaces and times. These concepts, however, must be examined in a contemporary and historical context $[14,15]$. This is particularly relevant today in the post-civil rights America where many educators subscribe to the rhetoric of a "post racial" social order and a colorblindness ideology $[16,17]$. By ignoring the historical and contemporary existence of racist structural systems foundational to educational organizations, educators bring into their classrooms a characteristic of superficial racial tolerance $[15,16]$. 
This study draws on the understandings of four generations of Black people from four different geographical locations. Their stories illustrate the need for further examination of the race-space nexus in the Black educational experience. The findings in this study suggest the way that students experience race may be different in smaller rural communities, with fewer populations of Black people, than in urban communities with larger populations of Black people. As such, there are salient implications for how students engage and participate inside and outside of school and how their identity development empowers or hinders them from acting on their own behalf when confronted with racism.

\section{Review of Literature}

2.1. The Intersection of Race and Space. Studies linking race and space have long been the domain of geographers $[18,19]$. Geographers engaged in the study of race have provided the foundational contributions to understanding that race and space are connected because racialized social processes are always spatialized [18, 20-27]. For example, Gruenewald [18] argues that researchers need to be intentional in broadening the examination of the intersections of race, space, and educational institutions. According to Gruenewald [18], contemporary educational research "takes little notion of space" (p. 620). He suggests that the research in education that makes the connection between the educational institutions and "real life outside of school" (p. 620) is very limited. Gruenewald's [18] work suggests that the paucity of research linking race and space is problematic, particularly since schools play a significant role in the production of the social and cultural space encompassed by children outside of school.

2.2. The Educational Research Connecting Race and Space. A common theme that permeates through much of the literature connecting race and space examines the relationship between educational funding juxtaposed against educational opportunities and outcomes [27, 28]. The work of Darling-Hammond [28] as well as that of Roscigno et al. [27] suggests that rural, suburban, and urban places have different educational opportunities based on economics. Their research examines the role of funding disparities based on geographical locations and the resultant production of educational and social inequalities.

Furthermore, Morris and Monroe [29] advocate for more research that pushes to the forefront the discussion of the interconnectedness of race and space particularly in the context of Black life and school. They redefine the scholarship on the Black-White achievement gap through their analysis of racialized space in the US South. While the literature discussed above is important, research involving the intersections of race, space, and the Black educational experience in a cross-generational context has been understudied [29]. This paper looks to expand the limited research on the intersection of geographies and race within educational settings.

Notwithstanding the significance of this literature, limited research has examined the intersection of race, space, and Black identity development. Duncan [22] examines how Black adolescents in predominately White spaces resist adapting an identity of racelessness as a strategy for academic achievement. His study suggests that Black students can be race conscious, Black-identified, and successful academically. Duncan's [22] work presents a counter-narrative to literature suggesting that Black children in predominately White schools need to take on a race-less identity as a means of fitting into the school culture and achieving academically. Lacy [25] and Partillo-McCory [26] examine the nexus of race, space, Black identity development, and education in their study of Black middle-class families. Their studies analyze the challenges facing Black families, as they feel forced to assume a race-less persona when living in predominately White suburban school districts.

Research focused on academic disparities has also contributed to the discussion of race, space, and the educational experiences of Black children. For example, O'Connor et al. [2] suggest that to advance conceptual and methodological research of Black educational experiences, a key specific emphasis needs to be placed on scholarship investigating the demands of particular geographic or sociohistorical contexts. For example, their study compares the academic disparities between White and Black children in rural and urban settings. The researchers conclude that failure to contextualize the Black educational experience limits our ability as educators and policy makers to better understand and improve educational opportunity for Black children. This paper extends this scholarship by contextualizing the Black experience in educational settings from an intergenerational perspective using a lens which examines the impact of geographical space and place.

\section{Theoretical Framework}

The theoretical frameworks that ground this study are critical race theory (CRT) [30] and the theory of racial space [19]. These interdisciplinary theoretical formulations are germane in understanding the multilayered structural educational inequalities of Blacks in the US. For the purposes of this study, these theoretical domains contribute to and inform the schooling experiences of Black people in intergenerational and geographical contexts.

3.1. Critical Race Theory. Critical race theory is used as a framework for this study because examining the experiences that Black people have within the educational system requires an investigation of race, racism, and Black identity development. This investigation must take place both in the educational institutions that Black students attend and the communities in which they live. This approach is critical since schools work as institutionalized microcosms of the society at large [31]. Critical race theory, as a theoretical framework, is useful in this study because it provides a way to theorize, examine, and challenge the ways that race and racism covertly and overtly impact the social structures, practices, and discourses that occur within educational settings [32]. Most importantly, CRT insists that we take into context the distinctive realities and lived experiences of Black 
people. Critical race theorists purport that without the voice of Black people contextualizing their daily lived experiences with oppression, a clear and critical understanding of their struggles with race and racism both in and out of the educational system would not be possible.

Critical race theory is an epistemological framework that emerged in the academy as a challenge to the positivist and legal discourse of civil rights $[33,34]$. Critical race theory challenges the historical underpinnings of how race is considered in law, society, and education [35]. For example, using the lens of CRT, the data collected during the in-depth interviews of this study is examined in search of themes which relate to the six tenets described by Delgado and Stefancic [30]: (a) racism is a normal fact of life and is endemic and ingrained in American life; (b) interest convergence which challenges race neutrality and colorblindness by suggesting that the interest of Blacks is only accommodated when they converge with the interest of powerful White people; (c) race is a social construction; (d) recognizing the experiential knowledge of Black people; (e) CRT is interdisciplinary; and (f) CRT works toward the elimination of oppression.

Critical race theory has been used by a number of researchers in education to analyze inequalities in educational settings $[33,34,36-39]$. Critical race theory in education seeks to challenge racist practices by highlighting the pedagogical dimensions of racism and by supporting pedagogical solutions rooted in antiracism [30, 40, 41].

3.2. Theory of Racial Space. Extending the exploration of the Black experience in school by examining both the impact of race and its various changes over time and space has provided a core basis for the theory of racial space [19]. This theory, developed by Neely and Samura [19], builds on the analysis of CRT by including the lens of space. For example, this work builds on the theoretical underpinnings of Knowles [24] who suggests, "the social construction of space illuminates the social constructions of race and vice versa" (p. 78). Neely and Samura's theory of racial space outlines four ways that racial and spatial processes intersect: (a) both race and space are contested; (b) race and space are fluid and historical; (c) race and space are interactional and relations; and (d) race and space are defined by inequality and difference.

Neely and Samura [19] suggest that examining race and racism within any milieu must be conducted within a sociohistorical context because the way in which race and racism has been defined and experienced by people changes over time and space. Race has often been constructed as an impermeable construct; however, race as a theoretical concept has manifested with a sense of fluidity based on time and space. They suggest that within any locale the lived experiences of Black people in the US have been influenced by social structures, spatial arrangements, and institutions, which over time change as historical conditions have changed and disappeared. Though the chattel slavery in the U.S. and overt racism of the South may not be present, an argument could be made that racism and racialized spaces still exist in this country and continue to impact the educational experiences of Black children [42, 43]. Neely and Samura [19] suggest that a spatial perspective on race can provide a useful lens for understanding racism and provide language for explaining its persistence in educational settings. The stories shared by the participants in this study support the idea that the cross-generational Black educational experience has been impacted by the intersections of race and space.

\section{Methodology}

A qualitative methodological approach, incorporating oral history interviews $[44,45]$, was used to collect first-person accounts of the educational experiences of 52 Black people reflecting four different generations. The interviews were conducted in four different cities in New York State. Oral history and the theoretical tenets of critical race theory and racial space theory were used because of my quest to change the focus from the voice of the elite, or academic, to that of the person at the ground level. The engagement of the Black educational experience is situated within the context of the lived experiences of the participants. Oral history methods illuminate how individuals experience, create, and make sense of the rules and roles of the social worlds they live in [46].

4.1. Participants. Participants were selected to join in this study if they self-identified as a descendant of slaves brought to the US. The criterion of slave ancestry was required because, as Ogbu and Simons [47] suggested, the Black people who are the descendants of slaves would respond to issues of Blackness and Whiteness differently than those in other Black communities. According to Ogbu and Simons [47], the historical and sociocultural adaptation of a minority group into US society is linked to "their response to their own history within the society and their subsequent treatment or mistreatment by white Americans" (p. 158).

The initial participants were intentionally selected from different social classes and political constituencies to create maximum variation. Maximum variation sampling requires a search for "disconfirming instances or variations" among a list of potential participants [48, p. 63]. Using snowball techniques, some participants recommended other people as potential participants in the study. In addition, the participants in this study ranged in age from 18 to 82 years, which included 27 women and 25 men. Based on the work of Strauss and Howe [49], the generational markers used to distinguish the participants were: Elders/Silent generation born during 1930-1949; Black Power/Baby Boomer Generation born during 1950-1969; Generation X/Hip Hop born during 19701987; and Generation Y/Millennial born during 1988-1995. Twenty-nine participants were identified as working class, 21 were identified as middle class, and two were identified as upper middle class.

4.2. Geographical Location. This study was conducted in four different communities in upstate New York; two of the communities are designated as rural geographical spaces and the other two are designated as urban geographical spaces. The US Census Bureau [50] defines rural locations as cities 
TABLE 1

\begin{tabular}{lccc}
\hline City & Population, 2010 & Percent Black persons, 2010 & Percent White population 2010 \\
\hline B1: & 47,376 & $11.4 \%$ & $77.6 \%$ \\
E: & 29,200 & $14.6 \%$ & $78.3 \%$ \\
S: & 145,170 & $29.5 \%$ & $65 \%$ \\
B2: & 261,310 & $38.6 \%$ & $50.4 \%$ \\
\hline
\end{tabular}

Source: (http://quickfacts.census.gov/qfd/states/36/3673000.html).

with populations of less than fifty thousand that are located in more rural settings and urban locations as cities with population of more than 150,000 . These cities are of different sizes, in terms of population and also percentages of Black and White persons living there (see Table 1).

The census data is one way to describe the differences between rural and urban spaces. The work of Knowles [24] suggests that the designations of rural and urban space are not simply about the physicality of the locations but also pertain to the people who occupy or use them in addition to the activities in which they are engaged. Space, according to Knowles [24], involves the nature of social relationships. For example, the rural spaces that have been commonly referred to as having "that small town feel" consist of neighborhoods filled with people who have close knit relationships. Participants living in rural spaces often designed their communities as places where "everyone knows everyone's business." The educational spaces in these rural communities were representative of the smaller population, each having one to two high schools, two middle schools, and four to five elementary schools. The rural communities lacked racial and ethnic diversity, with most participants describing their towns as predominately White with few Black families. This configuration of schools and community had been the same in both communities for all generations represented in the study.

In contrast, the urban communities had a higher proportion of Black people when compared to the rural communities. Across the generational periods in this study, these urban settings had large enough Black populations to have designated spaces called "Black neighborhoods" that were populated by large groups of Black and poor families. As one participant from the Elder/Silent generation shared, "S-had a real Black community growing up, it was like a village where we took care of our own." Many of these neighborhoods evolved as a result of the Great Migration of the earlyto-mid-20th century where Black families moved from the South to the North seeking employment opportunities. The urban community spaces have shifted over time, but still maintain neighborhoods where most of the participants lived in that were predominately Black. The urban spaces are characteristic of most cities in that people keep to themselves and life just seems to move at a faster pace.

4.3. The Schools. In the rural communities, the populations were smaller and the school system remained consistent across generations. While the more urban parts of the state dealt with issues of segregation and policies to integrate the schools, the rural community did not. There was and continues to be only one public high school in each of the communities explored in this study and most residents sent their children there. There were two middle schools and 4 to 5 elementary schools in the rural communities and placement in these schools was based on the neighborhood that one resided in. The Blacks living in the rural communities were integrated into the neighborhoods, so there were no critical masses of Black students in any of the elementary and middle schools.

In the two urban cities in this study de facto segregation existed in schools, caused by segregated neighborhoods and school policy requiring that students attend their neighborhood school. In both of the urban communities in this study, the schools attended by members of the elder generation were predominately Black as a consequence of the neighborhood school policies. As the Black Power generation began their school journey, New York State was faced with court mandates to desegregated public schools [51]. As a result of these mandates, a number of participants of the Black power generation participated in forced busing programs. These programs primarily worked to bus Black children to predominately White neighborhoods and schools. Policy makers intended to bus Black children to predominately White areas, while White children were given the option to volunteer for busing to one of the central schools, created to attract them into the historically Black neighborhood schools. These policies proved inadequate due to White flight to the suburbs and eventually the urban school districts returned to neighborhood schools due to budget constraints. The consequence of the failed integration policies to the Hip Hop/Generation X and the Millennial/Generation Y participants living in urban settings is a return to racially segregated schools dominated by poor students of color which look very much like the schools their grandparents from the Elder generation attended. Moreover, according to a recent report by the Civil Rights Project, empirical research has demonstrated that New York State has been severely and disproportionately impacted by segregated school systems in the US [51]. This study suggests that through the voices of the participants that even as school environments and educational opportunities have changed over time within a geographical space or community, the way that Black children experience race/racism in the context of school and community is similar across the generations.

4.4. Data Collection. Oral history interviews were conducted with each participant to collect an in-depth account of each person's educational experiences. The interviews ranged from 
four to six hours, with breaks to get snacks or in some cases to have a meal through which the discussion continued. To ensure privacy, the interviewees chose their interview location. One characteristic of this type of qualitative research is conducting research in a natural setting in a place where the participants are comfortable [52]. The scheduling of the interviews was based on the availability of the participants. Oral history interviews undertake an in-depth account of personal experiences and reflections. In this case, each participant was provided whatever time he or she needed to share their stories about their schooling experiences. The participants were asked to reflect on their educational experiences from their earliest memories through the end of high school. The oral history methodology allowed the researcher to listen to the participant's life narratives utilizing a small number of cues. The life narratives focused on fundamental life experiences in their respective communities and their experience attending to school. All the interviews were digitally recorded and transcribed verbatim. Pseudonyms were used for participant confidentiality. The study was put through the full review process of the researcher's university Human Subjects Research Review Committee and was fully approved by the review board.

4.5. Researchers' Positionality. In qualitative studies, the positionality of the researcher is an important component in the research process. As Jones et al. [53] suggest, the positionality of the researcher will influence how the data is collected, analyzed, and interpreted for meaning. This study considers the perceptions that Black people have of the education system in the US. As a Black woman who has navigated through school systems in many parts of the US, I have a strong interest in and opinion about how the school system affects the lives of Black people. I consider the educational system to be one of the most important and influential institutions of the social systems in which we engage. I saw first-hand in my own family how the educational system could set some on a path to higher education and meaningful employment while simultaneously directing others to a path taking them from school dropout to prison and lives of subsistence. The educational system impacted many of the opportunities I have had in my life and it continues to impact the life chances and life choices of Black people across the U.S. As a Black woman engaging in research about Black people, I bring strength to this research in my ability to stridently understand the racialized identities of Black people. My "emic" perspective of the historical positioning of Black people in the U.S. juxtaposed with my knowledge of the educational system both as a student and as an educator strengthens my position as researcher in this study. It has been articulated by scholars such as Tillman [54] that researchers do not have to come from the racial or cultural community under study to conduct research in, with, and about that community. Hatchett and Schuman [55] tell us, however, that "the race of the interviewer is significant when assessing subjects responses to topics such as education" (p. 525). The goal of this researcher is to study the phenomenon called the Black educational experience and arrive at some "truth" which is representative of the researcher and participants' voices, perspectives, and narratives, while not privileging my voice. According to Nieto [56] researchers can acquire this "truth" in research when they value and listen to the self, to others, and to the self in relation to others [57]. Being a Black woman who has navigated through the halls of many educational institutions, I realize that my experiences have the potential to both collide and intersect with those of the participants in this study. As a researcher, it is my charge to be vigilant and mindful of the objective of the project- to hear the voices of the participants and account for them.

4.6. Data Analysis. Using tenets of ground theory analysis [58], data collection and analysis occurred simultaneously. The researcher used a constant comparative analysis of data, including reviewing memos, observations, and interview transcripts to identify recurring patterns [53]. Based on the work of Jones et al. [53], constant comparative analysis engages the researcher in a process of collecting and analyzing the data simultaneously at "all stages of the data collection and interpretation process, and results in the identification of codes" (p. 44). Open coding was used to identify concepts and categories. The first step in performing open coding is to view the documents for large passages of meaningful text, devoid of predefined headings or topics. Broad descriptors were attached to these codes. Next, the codes were reviewed for commonalities and refined by either clustering into existing codes, refining code names, or eliminating codes altogether. This resulted in the generation of code families or categories. Texts marked with the same code were clustered together and reviewed for coherence and adherence to the code definition. Meaningful texts were reviewed to make clear core segments. Finally, codes were compared with one another for relational value. The codes were then analyzed for interconnectedness and interrelationships within and between one another. This process continued until the data reached a point of saturation [58]. In the final analysis, this process helped to solidify and cluster the data into the two major themes presented in the findings section of this study. In discussing the findings, excerpts are presented from the participants' responses verbatim to preserve the essence of their voices. Pseudonyms are used to maintain the anonymity and confidentiality of each participant.

4.7. Credibility and Trustworthiness. To ensure the data's "trustworthiness," member checks were conducted by returning the transcribed interviews to all participants to check for accuracy and clarity [59, p. 313]. As the study progressed, participants were provided an opportunity to review the researcher's interpretation of the data. The participants did not raise any issues with the way the stories about their experiences living in their respective communities as well as their educational experiences were represented. Sources from which triangulation occurred in this study were data triangulation, as well as site triangulation. Data triangulation occurred when another source, such as a document or another interview substantiated an interviewee's memory. The distinct geodistant location of the cities along with their 
separate and distinct geographical, historical, and cultural contexts provided an additional triangulation source.

4.8. Limitations. There are several limitations in this study. The first being the relatively smaller number of participants in each location; although there were 52 participants in the study, each geographical location had only 12-14 participants. Additionally, this study was conducted in four cities in upstate and western New York, creating geographical limits to its generalizability to other parts of the US. Despite these study limitations, the author provides thick descriptions using the oral histories of the participants to allow readers to assess the transferability of the findings to similar contexts. Moreover, during the interviews, the participant's comfort level with the researcher and the questions asked might have influenced the extent to which a participant shared their experiences, especially in matters they perceived as sensitive or too personal; therefore, a degree of caution should be exercised when interpreting these findings.

This study also involved recording the oral histories of participants sharing their educational experiences starting at kindergarten through to high school. For the older generation of participants whose ages ranged from 63 to 82, this involved remembering events that were older than the entire life span of some of the younger participants. There are problems that one cannot prevent when dealing with an individual's memory such as, an individual's ability to recall experiences. The recall of other participants, along with documents supplied by the participant (i.e., photographs, newspaper clippings, articles, and books written about the communities) was used when possible as corroborating evidence.

\section{Findings}

In this section, the two main themes, which emerged from the interviews, are summarized. The first theme discusses how many of the participants living in the rural spaces described race and racism as not being significant features in their lives during their K-12 schooling experiences. For the second theme, participants in living urban spaces describe race and racism as being central to their K-12 schooling experiences. Both themes show that there is a geographical context to how the participants perceived the salience of racism in their school and community experiences. This was evidenced by the participants' responses when they communicated stories about their lived experiences growing up in and attending schools in their respective communities. The themes are delineated and quotes from participants are presented to preserve the essential aspects of their experiences.

5.1. Holding onto Colorblindness: Race \& Space in the Rural Experience. The participants living in rural spaces discussed their colorblind experiences both in the communities where they lived and in the schools they attended. The school system in both of the rural communities visited remained static in terms of the number of schools. Each had one high school, two middle schools, and 4 to 5 elementary schools. They were proud of the colorblind communities, where "everyone just fit in." Over time, as they told their personal stories about their communities and the schools they attended, most of the participants living in rural areas shared stories that suggested that they were not always living in a space where, "everyone just fit in" but their lives were very much intertwined with race and racism both in and out of school. For example, Ike, a retired physical education teacher and a participant from the Elder generation, described his town as one in which race was never an issue. He felt that growing up in a rural setting the operative word to describe his experiences with race would be, "colorblind." Ike shared that he really never viewed race as a factor in his schooling experience. In fact, Ike felt that the community was so inclusive that sometimes he even "forgot he was Black." Reflecting on his childhood and his high school experiences he explained,

...the schools was so good that a lot of times I did
not realize that I was Black until I would go to
the bathroom and see in the mirror and I realize,
oh my God, I'm Black...they made me feel I was
a part of them...they was treating me as one of
them.

Rosie, a 67-year-old production worker, also from the Elder/Silent Generation described a similar race-neutral experience growing up in a different rural area. Rosie shared, "... [I] really didn't feel separate from them because I had white friends. .. it was a pleasant neighborhood. . . at school I think they [teachers] treated us all equally."

Other members of the Elder/Silent generation-Theresa, Wes, and Billie-expressed similar feelings as Ike and Rosie and shared stories which showed they also constructed their rural communities as spaces where racism was practically nonexistent. Black residents living in these rural spaces across all the generational groups expressed a similar construction of rural spaces as being bastions of racial harmony. Both Theresa and Wes shared that they just never had "any problems around race, we never even talked about racism." Similar to these members of the Elder/Silent generation, Black Power generation members, and college graduates Carl, a 50-year-old army veteran from the Black Power generation, and Peaches, a single mom echoed the sentiments of the Elder/Silent about race and school. A quote by Carl sums up their perceptions of their school experience. He shared "I never really had anything like [a] racist experience. In school everyone just fit in." Carl and Peaches were both middle class college graduates, but these feelings that "everyone just fit in" were echoed over and over by members of the Black Power generation living in rural spaces. Mike, another rural resident from the Hip-Hop generation is a high school graduate who works as a welder. He shared that, "I never really had problems with prejudice in school. It was not until I started working that I got called a 'Nigger', but at school we were all the same, just kids." Peggy, a high school graduate who works as a hairdresser and Pete, a factory worker, expressed beliefs similar to that of Mike, and other participants from rural spaces sharing, "everyone just fit in at school."

The theme of a race neutral existence among residents of the rural communities continued with the younger participants from both the Hip-Hop and Millennial Generations. 
For example, Uthman, a 35-year-old student enrolled in a local university shared that, "Racism doesn't seem to be a problem, at least in my experience." Similarly, Reyan, who at 18 was the youngest female participant from the HipHop/Millennial Generation, shared "I haven't really experienced discrimination in school; everyone has the same opportunity. It's a matter of taking advantage of your opportunity."

Across four generations the participants living in rural settings spoke about their communities and schools using a discourse associated with a colorblind ethos. Though they spoke of their communities as colorblind, they also shared stories depicting experiences, which most critical race theorists would construe as examples of racism. Yet in telling these stories, they did not waiver from their original description of life in a community where race is not a salient part of their life experience. The acts of racism they experienced were just dismissed and treated as normal life interactions. Revisiting earlier statements juxtaposed against stories that elucidated their experiences with racism illustrates the inconsistencies in the real and perceived lived experiences of Black people in the rural settings.

Ike illuminates this finding when he shared that he "forgot he was Black." The following story shared by Ike suggests that race may have been a more salient feature of his life than he indicated. Although Ike claimed that he might have forgotten he was Black, the story that follows suggests that his schoolmates had not forgotten he was Black,

....[Field trips] used to be [at] Glenwood Park and it was an all White park...and when we used to go there you would hear mocks from... White kids would yell "there's a 'Nigger". Sometimes the friends from my school would protect me and they would tell them "Shut up" but other times I was on my own...I'd just keep quiet...

Ike clearly experienced an incident of racism based on this story, yet he never makes a claim that he did. Ike's response suggests that he did not see this behavior as atypical. Ike was not alone in his acceptance of racist behavior as normalized. Similar to Ike, Rosie shared a story, which deviated from her initial assertion that she never experienced racism in school. Rosie shared a story about a teacher who she felt never called on her to answer a question in class because she was Black:

I was the only Black student in the class when I raised my hand, she'd overlook it every time. . one day I had the courage to go and ask her, "Why?" You know, and um, I can remember asking her, "Is it because I'm your only black student?" Of course, she said "No" but I am not sure.

Theresa, who shared that she "never really had anything..." also noted, "I never went to their [White students] houses, and they never came to mine. We saw each other in school, but they didn't want much to do with us [Black students] outside of school." Carl discussed a similar experience about race relations in his community, "Everyone just fit in." For example, Carl shared the following incident which challenges his initial statements and speaks of some of the difficulties he had experience because of his race:

They were always incidents...like the namecalling, and if you liked a White girl, you were okay for a friend but you couldn't be my boyfriend because my parents wouldn't like it...My best friend in the 10th grade was white and his girlfriend threatened to break up with him if he didn't drop me as a friend, because I was black.

This trend continues across generations as reflected in the life narrative of Kyle, a participant from the millennial generation who described a racist rant by one of his teachers as not really being a problem:

I had this one teacher, who I really liked, he was such a cool teacher and one day...he was saying there was no wrong in saying Spic, Spic, Spic or Nigger, Nigger, Nigger and all that stuff... and I don't know... a lot of kids didn't like him...The thing about that teacher was he never bit his tongue; whatever came out of his mouth came out of his mouth. I didn't really see him as prejudice.

Kyle further shared that he did not see his teacher's statement as racist but rather perceived it as funny. He treated the teachers' remarks as if they were part of a normal conversation, as if using racial slurs was a normative and acceptable behavior. Other participants like, Lois, a high school graduate and stay-at-home mom and Uthman, who was in the last semester of his associates degree at the local community college, both from the Hip-Hop/Gen X generation, also lived in rural settings and had similar stories that contradicted their claims of having never experienced racism. Reyan, who proclaimed early in her interview that she had "never experienced or witnessed discrimination," directly contradicted this claim, as illustrated in the following example. Reyan shared a story about a fight in her high school, “... police got called and were abusing mostly Black kids...throwing them up against walls and handcuffing them... only Black kids got arrest none of the Whites."

Across generations participants living in rural settings would use discourse to describe their communities as nonracial and then share stories that showed explicit racism.

Their stories suggest that racism had almost been normalized in the rural community. The acts of racism experienced by the participants were not met with resistance, but were treated as acceptable and normal behavior. This is a distinctly different response from those participants living in urban settings.

5.2. Experiencing Racism: Race and Space in the Urban Experience. The participants in this study who lived in urban settings were more forthright in their discussions about their experiences with racism in school. They had a more heightened sense of race consciousness and were unafraid to openly discuss their experiences with racism growing up. Their stories suggest that they were not trying to fit into 
predominately White spaces but rather they perceived being pushed out of White spaces.

Ray, a 73-year-old retired cook, from the Elder/Silent Generation moved with his family from the Deep South to the North as a child. He also began his schooling in New York attending a predominately White school. However, Ray's narrative is different from Ike's because Ray grew up in an urban setting and makes it clear that he experienced racism in school. Ray never talked about fitting or being part of a colorblind school community as Ike did. He shared:

I was the only "Colored" kid there, and the racism I experienced, at times, with the name calling was there "Nigger" this [and] "Nigger" that and from other kids and sometimes teachers. At times the teacher would treat you like they realized that maybe you're not up to par enough, because you're "Colored"... One day I got moved to another school, they say it was the school for dummies. I didn't learn nothing there, the kids was so bad...There was mostly colored sent from my school.

Ray's narrative is straightforward. He is clear about his experience with racism in school and what, in his assessment, led him to attend alternative school for "dummies." Through Ray's story the familiar but problematic phenomenon of Black males being pushed into remedial and special education classes emerges. Ray clearly articulated that he experienced racism in school. It was manifested in the form of namecalling and being pushed into remedial education or, as he calls it a "school for dummies" where according to him, he did not learn anything. Ray's experiences with racism are revealing and also representative of the experiences of many of the participants living in urban settings. Their stories give an account of the prominence of racism in their schooling experiences.

In another example, Johnny, a 72-year-old retired factory worker from the Elder Generation, had similar experiences with teachers who constructed Black students as academically inferior. Specifically, he shared that “... [teachers] would treat you like they realized that maybe you're not up to par enough, because you're Black. . they [teachers] didn't think we could catch on." The construction of Black students using a deficit model is a theme that is discussed by a number of participants living in urban spaces across generational groups.

From the Black Power Generation, participants like Leslie and Joy share experiences in the schools that they attended as a consequence of being forcibly bussed from their home communities to predominately white schools. Leslie, a 52year-old bus driver, shared her own experience with teachers who considered her uneducable, "I hate to say it but most White teachers, already think that Black kids is not gonna amount to nothin'. But there were some Black kids, like me, that want to learn and that come to school to learn." Similarly, another participant from the Black Power Generation, Joy, a 51-year-old, a former teacher's aide who is now on disability, shared that not only did her teachers have low expectations for Black students, but the educational environment was not welcoming for Black students. Joy shared her experience, as a student who was a participant who was bussed to a predominately white high school in a section of town that she claims was known to be historically hostile to Blacks:

We had more Caucasians than there was of us, of African-Americans. It was a little different in environment. [They were] racist. We didn't belong there...They said it was their school, [and they] didn't think we belonged there.

And they tried hard to make us feel it...name calling you known_. Teachers treating us like we were stupid...I never felt safe.

Most of the participants living in the urban areas lived in spaces that were predominately Black. Their experience was different from those in the rural areas because those who lived in urban settings left the safety and comfort of their home communities to go to school and entered into educational spaces where they often felt they did not belong and were not welcome. Joy did not accept the racism she experienced as normative behavior. When Joy left her home and was bussed to a predominately White school in a predominately White neighborhood, she shared about feeling as if when she walked through the school doors she entered into "into another dimension, like the twilight zone; a place where people are crazy and hate Black people." Other participants, like Tameka, a young single mom who just turned 20 years old echoed Leslie and Joy's sentiment about teachers not caring about the academic progress of Black students in her school saying, "I used to hear teachers say, 'Well, I got my degree, you got yours to get.' They'd just write us off. ..just sit at the desk and not teach."

The participants in this study living in urban areas continuously shared their belief that schools considered them uneducable. School was not a welcoming place but a place where they felt unwelcomed and were expected to fail. A place where Kelvin, a 30-year-old unemployed member of the Hip Hop Generation shared that, "They thought cause I was African American from the projects, or something, I didn't belong in their school. Like I didn't know how to act, but I did."

\section{Discussion}

This study contributes to the understanding of the Black school experience in rural and urban settings using an intergenerational context. The central finding of this study is that living in a rural versus an urban geographical location influences a Black student's perceptions of racism and racial identity development in the context of school and community. For the participants in this study, perceptions of the salience of racism in their lives were connected both to their own sense of Blackness and the geographical location of their community (i.e., rural or urban). The examples in the findings show that across generations there was a difference in the way the respondents in this study reported their experiences with incidents of racism depending on whether they lived in a rural or an urban community. The language they chose to describe incidents suggested that those living in rural communities were more likely to dismiss racism as a reason 
for negative interactions they had with White people. Those participants living in urban communities were more likely to cite racism as the reason for negative interaction with White people. The community space and the relationships developed between the White and Black communities impacted how Blacks saw themselves in these predominately White rural and urban communities [19]. The theory of racial space purports that racial identity construction is shaped by spatial arrangements [19]. This idea is supported in this study and is observed through the lives of those living in rural spaces who constructed their schools and communities as colorblind and themselves as race-less. For the participants in this study, who lived in the rural communities, Blacks and Whites lived side-by-side experiencing very little residential segregation as compared to those living urban settings. The Blacks in these communities lived in spaces where cultural norms discouraged speaking about race, as one participant Junie from the Black Power generation shared, "we just don't speak about race things here."

The impact of the intersection of race and space is also manifested in the lives' of those living in urban spaces, whose keen awareness of the racial inequalities and ideologies reproduced in their schooling experiences situated them as race conscious. They subscribe to the basic CRT belief that racism is an ordinary everyday life experience. While this study focused on the Black residents in the communities who self-identified as the descendants of African slaves, future studies should be more intentional in their investigation of the intergenerational experiences of White people and other ethnic communities in rural and urban settings.

This study yielded two themes, the first being that participants living in rural areas were likely to express a self-conflicting view of the salience of racism in their lives. This is evidenced in the stories shared by rural residents when they used the discourse of "colorblindness" and raceneutrality to describe their communities yet shared stories indicating their very real experiences with racism in the same community. Even when participants dwelling in rural areas were confronted with overt racism they treated it as normative and acceptable behavior. Based on the work of Fordham [60], this behavior is not unusual for Black people who are disconnected from a Black communal collective. In rural areas, where Blacks are often isolated, Fordham suggests that Blacks might use a strategy of racelessness or race avoidance as a way to fit into communities that are predominately White.

There are a limited number of scholars who have looked at intersections of space and Black identity in rural settings; the most recent work comes from researcher's Garland and Chakraborti [61] in England. Their work suggests that in predominately White rural communities, there is an implicit assumption that racism is not a problem because there are so few people of color living there, it does not matter. The CRT tenet of interest convergence could suggest that race in these communities would be dismissed as a problem because a community discussion on race is not a concern of White people in the community $[62,63]$. As long as no one raises the issue of racism in the schools, the implicit assumptions are that racism is not a problem.
The work of Garland and Chakraborti [61] suggests that when numbers of Black residents are small it prohibits them from coalescing and forming real community so they try to just fit in, adopting a race-less identity. The problem with adapting a race-less identity is that the Black residents in the rural setting really "don't 'just fit in." As the narratives illustrate, most of the participants might have started with a claim of not experiencing racism but, eventually in their stories an experience with racism was articulated. Many of the rural participants tried to see their world through the "rose colored glasses" of color blindness, but found there were always situations in which they experienced racism in overt and subtle ways.

The second theme in this study showed that the participants living in urban settings believed that racism was a prominent feature in their day-to-day lives. For these participants, racism permeated all the spaces they inhabited whether in school or in the community. The participants in urban areas across generations shared stories of experiencing more overt forms of racism. Some felt that they were being treated with blatant hostility in school because of their Black skin. This was true for those who attended neighborhood schools as well as those who participated in the mandated forced busing programs. Their narratives support their perceptions of being judged by their teachers and classmates and seen as being inferior or uneducable of their race. Participants shared stories in which they expressed incidents where they were being treated as if they "weren't up to par," "not smart enough to go to college," or "they were stupid." This cultural frame suggesting that White teachers view Black children as innately less capable and inferior to White children is supported by decades of scholarship [3, 10, 15, 64-67]. The narratives in this study bear witness to instances when teachers treated Black people across generational periods as intellectually incompetent. The consequences for Black children are dire, as Perry et al. [3] write "the academic success of Black children can be interrupted by teachers who explicitly or subtly convey a disbelief in the child's ability for high academic achievement (p. 79)."

Along with being treated as academically deficient and inferior, some walked into educational institutions and were constructed as social deviants and singled out as suspicious or possibly criminal simply because, they lived in a racialized spaces, like "the ghetto" or "the projects" sharing thoughts like, "they thought cause I was...from the projects...I didn't belong in their school." Interestingly, while participated used broad terms such as "ghetto" or "project" to describe the spaced in which the lived, no data was collected to discern how living in these spaces impacted the educational experiences of the participants.

A number of participants who lived in urban areas expressed a sense of not belonging because of the treatment they received from their teachers and classmates. These participants were different from their counterparts in the rural communities who were uncomfortable discussing racism. Those from the urban areas described in great detail and without hesitation their experiences with racism. Fordham [60] suggests that the participants from urban areas had the ability to talk about race in a way the rural participants 
could not because the urban dwellers in this study either lived in or had close ties to predominant Black communities. Their close associations with other Blacks translated into a raised sense of racial consciousness. This association accounts for the urban participants having a more race conscious critic of their school experience [60]. According to Zuberi and Bonilla-Silva [68], the participants' raised consciousness would allow themselves to be keenly aware of systems of racialization inhibiting them from normalizing even slight acts of racism. The residents in the rural towns had a racial consciousness level that allowed them to accept as normal, situations that those participants living in urban settings would see as racist. For the participants in this study who lived in the rural communities, Blacks and Whites lived side by side experiencing very little residential segregation as compared to those living urban settings. The Blacks in these rural communities had a deep sense of local identity and strong sense of belonging to the community. They lived in spaces where cultural norms discouraged speaking about race, as one participant Junie from the Black Power generation shared, "we just don't speak about race things here." This idea is consistent with Brown and Schafft [69] who suggest that rural spaces operate as White spaces and the sociocultural norms would support a public discourse that purports that all races are the same, thus denying the existence of racial oppression their rural communities.

In contrast, most adults living in urban communities both White and Black are likely to see racial inequalities in their communities and educational institutions [70].

Fordham [60] suggests that the larger more urban communities use the idea of collective Black achievement as a shield to help them navigate through society and develop a strong Black identity. Tatum [71] supports this idea suggesting that belonging to a Black collective is foundational to the development of a strong Black identity. According to Tatum [71], developing a racial identity is the "process of defining for oneself the personal significance and social meaning of belonging to a particular racial group" (p. 16).

The research presented in this study on issues of identity suggest a need for more research with the potential to move theoretical, scholarly, and policy discussions on the achievement gap forward by foregrounding the saliency of geographical location in shaping Black student's identity. This also would involve educational and social experiences, particularly in rural and small urban areas in the North. As Morris and Monroe [29] suggest, developing a more complex understanding of the nexus of race, space, and Black identity and schooling needs an interdisciplinary and collaborative effort from scholars across many disciplines.

The intent of this research was to give voice to Black people who participated and represented four generations of Black experience in educational settings. Through their stories emerged the finding that the space or geographical location of where they lived impacted their perceptions of the salience of racism in their lives. Their experiences suggest that the importance of using both CRT and a lens of racial space provides a better understanding of the racial inequities and Eurocentric ideologies. One Eurocentric ideology that permeates educational institutions is colorblindness; an idea that suggests that ignoring or overlooking racial and ethnic differences promotes racial harmony $[42,43]$. Research has shown that these ideologies operate within educational institutions and challenge the lives of Black people as they navigate the K-12 educational system $[16,17]$.

6.1. Significance/Implications. The findings in this study suggest that racism continues to be a critical problem in the educational experiences of Blacks in the US. The participants' stories about their experiences with racism in schools run counter to the dominant educational institutional discourse of colorblindness $[11,15,17,37,43]$. One problem that educators face relates to the misinterpretations of what racism looks like in the lived experiences of the Black students they teach. These educators often have interpretations of what racism looks like based on a model that suggests racism is individual, overt, and violent $[42,72]$. Sue [72] suggests "most people in America see racism as individual acts, those overt, conscious and deliberate individual acts meant to harm, place at a disadvantage or discriminate against Blacks" (p. 7). While racial progress has been made, one important implication of this study would be to help teachers understand that racism experienced in contemporary times does not necessarily fit their standard definition but rather as racial space theory purports has morphed into "more insidious and subtle racialized institutional practices, which are more invisible and more indirect and yet continue to oppress" [72, p. 8]. Sue [72] indicates that these more subtle forms of racism which he calls racial microaggressions continued to be perpetuated in the form of "daily verbal, behavioral, and environmental indignities" and have damaging consequences for Black students.

A practical implication of this study is for educational administrators to find ways to make teachers in the field and in training aware of the continued need for educational practices and policies that incorporate a consciousness related to the influence of overt and covert forms of racism in the routine experiences of Black children and other children of color. This awareness could contribute to more meaningful opportunities for Black children in educational settings. Researchers have contended that the use of oral narratives and the counter narratives of Black educational experiences need to be told so that educators understand Black educational experiences as Blacks live it $[3,11,15,73]$.

Another implication of this study challenges the notion of the one size fits all approach to educational policies and programs directed at Black children. Educational disparities, as outlined in the studies, presented in the National Center for Educational statistics studies [4], suggest that educational disparities between Black and White children transcend social class and geographical location considerations. The findings in this study suggest that the way that students experience race may be different in smaller communities with smaller populations of Black people than they are in communities with larger populations of Black people. This might infer that approaches to eliminating educational policies aimed at reducing disparities in the Black/White achievement gap may need to be different for these communities. For example, 
educational policies and programs that may work in large urban centers such as New York City may not necessarily work in smaller rural communities. Educational research that suggests that Blacks are a monolithic group facing the same issues across space and time ignore the variations in educational experience [2]. The result is that opportunities to inform educational policy and to improve the educational chances of Black children are missed.

Research using the lens of racial space is limited particularly in the context of Black education. Using the lens of racial space in this study unlocked the finding that geographical location impacts the salience of racism in the lives of Black students. Additionally, studies using both oral history methodology and a racial space framework need to be conducted that expand the focus to Black families whose familial histories lie not only in New York but in other rural and urban communities in the Northern part of the United States. Such a study could provide a comprehensive examination of the experiences of Black youth akin to the work of Anderson's [74] classic study on the schooling experiences of Blacks in the South.

\section{Conclusions}

Current examinations of the Black educational experience are undermined by the suggestions of a post-racial society and the discourse of colorblindness [17]. These frameworks often discount the structural explanations for the variegated problems that Black youth encounter while in school. For example, this discourse has a tendency to undermine the critical role of structural racism in the educational system. Secondly, this argument suggests that personal agency is the solution to the problems facing Black children in schools. Educational researchers and policy makers need to explore how historical and contemporary social forces inform their knowledge of racial structures and practices that sustain and reward everyday racism [39]. As Black students continue to experience disenfranchisement in school settings, a more active search for strategies that enhance educational opportunities for Black students is needed. Looking at racial phenomena through a lens of space offers teachers, administrators, and researchers an opportunity to locate and understand more intimately the racial politics and the struggles Black students face daily as they navigate racial hierarchies.

\section{Conflict of Interests}

The authors declare that there is no conflict of interests regarding the publication of this paper.

\section{References}

[1] C. Jencks and M. Phillips, "The black-white test core gap: an introduction," in The Black-White Test Score Gap, C. Jencks and M. Phillips, Eds., pp. 1-51, Brooking Institution Press, Washington, DC, USA, 1998.
[2] C. O'Connor, A. Lewis, and J. Mueller, "Researching "Black" educational experiences and outcomes: theoretical and methodological considerations," Educational Researcher, vol. 36, no. 9, pp. 541-552, 2007.

[3] T. Perry, C. Steele, and A. G. Hilliard, Young, Gifted, and Black: Promoting High Achievement among African-American Students, 2003.

[4] A. Vanneman, L. Hamilton, J. Baldwin Anderson, and T. Rahman, Achievement Gaps: How Black and White Students in Public Schools Perform in Mathematics and Reading on the National Assessment of Educational Progress, National Center for Education Statistics, Institute of Education Sciences, U.S. Department of Education, Washington, DC, USA, 2009.

[5] J. B. Diamond, "Still separate and unequal: examining race, opportunity, and school achievement in "integrated" suburbs," The Journal of Negro Education, vol. 75, no. 3, pp. 495-505, 2006.

[6] E. M. Horvat and C. O'Connor, Eds., Beyond Acting White: Reframing the Debate on Black Student Achievement, Rowman \& Littlefield, Lanham, Md, USA, 2006.

[7] G. Ladson-Billings, "From achievement gap to education debt: understanding achievement in U.S. schools," Educational Researcher, vol. 35, no. 7, pp. 3-12, 2006.

[8] J. U. Ogbu, Black American Students in An Affluent Suburb: A Study of Academic Disengagement, Lawrence Erlbaum, Mahwah, NJ, USA, 2003.

[9] A. Thernstrom and S. Thernstrom, No Excuses: Closing the Racial Gap in Learning, Simon \& Schuster, New York, NY, USA, 2003.

[10] L. Delpit, "Multiplication is for White People": Raising Expectations for Other People's Children, The New Press, New York, NY, USA, 2013.

[11] N. Lopez, Hopeful Girls, Troubled Boys: Race and Gender Disparity in Urban Education, Routledge, New York, NY, USA, 2nd edition, 2012.

[12] R. J. Skiba, L. A. Shure, L. V. Middelberg, and T. L. Baker, "Reforming school discipline and reducing disproportionality in suspension and expulsion," in The Handbook of School Violence and School Safety: International Research and Practice, S. R. Jimerson, A. B. Nickerson, M. J. Mayer, and M. J. Furlong, Eds., pp. 515-528, Routledge, New York, NY, USA, 2nd edition, 2011.

[13] R. J. Skiba, L. Shure, and N. Williams, "Racial and ethnic disproportionality in suspension and expulsion," in Disproportionality in Education and Special Education, A. L. Noltemeyer and C. S. Mcloughlin, Eds., pp. 89-118, Charles C. Thomas, Springfield, Ill, USA, 2012.

[14] T. Holt, The Problem of Race in the 21st Century, Harvard University Press, Cambridge, Mass, USA, 2000.

[15] A. Lewis, Race in the Schoolyard: Negotiating the Colorline in Classrooms and Communities, Rutgers University Press, Piscataway, NJ, USA, 2003.

[16] E. Bonilla-Silva, "Anything but racism: how sociologists limit the significance of racism," in White Logic, White Methods: Racism and Methodology, T. Zuberi and E. Bonilla-Silva, Eds., pp. 137-152, Rowman \& Littlefield Publishers, Lanham, Md, USA, 2008.

[17] H. A. Neville and G. H. Awad, "Why racial color-blindness is myopic," American Psychologist, vol. 69, no. 3, pp. 313-314, 2014. 
[18] D. A. Gruenewald, "Foundations of place: a multidisciplinary framework for place-conscious education," American Educational Research Journal, vol. 40, no. 3, pp. 619-654, 2003.

[19] B. Neely and M. Samura, "Social geographies of race: connecting race and space," Ethnic and Racial Studies, vol. 34, no. 11, pp. 1933-1952, 2011.

[20] S. J. Ball, M. Maguire, and S. Macrae, "Race', space and the further education marketplace[1]," Race Ethnicity and Education, vol. 1, no. 2, pp. 171-189, 1998 (Hungarian).

[21] D. Delaney, “The space that race makes," The Professional Geographer, vol. 54, no. 1, pp. 6-14, 2002.

[22] G. A. Duncan, "Space, place and the problematic of race: black adolescent discourse as mediated action," The Journal of Negro Education, vol. 65, no. 2, pp. 133-150, 1996.

[23] K. Gulson, "A white veneer: education policy, space and "race" in the inner city," Discourse, vol. 27, no. 2, pp. 259-274, 2006.

[24] C. Knowles, Race and Social Analysis, Sage, London, UK, 2003.

[25] K. Lacy, Blue-Chip Black: Race, Class and Status in the New Black Middle Class, University of California Press, Berkeley, Calif, USA, 2007.

[26] M. Partillo-McCory, Black Picket Fences: Privilege and Peril among the Black Middle Class, University of Chicago Press, Chicago, Ill, USA, 1999.

[27] V. J. Roscigno, D. Tomaskovic-Devey, and M. Crowley, "Education and the inequalities of place," Social Forces, vol. 84, no. 4, pp. 2121-2145, 2006.

[28] L. Darling-Hammond, The Flat World and Education, Teachers College Press, New York, NY, USA, 2007.

[29] J. E. Morris and C. R. Monroe, "Why study the U.S. South? The nexus of race and place in investigating black student achievement," Educational Researcher, vol. 38, no. 1, pp. 21-36, 2009.

[30] R. Delgado and J. Stefancic, Critical Race Theory: An Introduction, University Press, New York, NY, USA, 2001.

[31] A. L. Sullivan and E. A'Vant, "On the need for cultural responsiveness," Communique, vol. 38, no. 3, p. 8, 2009.

[32] T. J. Yosso, "Whose culture has capital? A critical race theory discussion of community cultural wealth," Race Ethnicity and Education, vol. 8, no. 1, pp. 69-91, 2005.

[33] G. Ladson-Billings, "Just what is critical race theory and what's it doing in a nice field like education?" International Journal of Qualitative Studies in Education, vol. 11, no. 1, pp. 7-24, 1998.

[34] G. Ladson-Billings, "Critical race theory", in Handbook of Critical Race Theory in Education, M. Lynn and A. D. Dixson, Eds., Routledge, New York, NY, USA, 2013.

[35] R. Delgado and J. Stefancic, "Discerning critical moments," in Handbook of Critical Race Theory in Education, M. Lynn and A. D. Dixson, Eds., Routledge, New York, NY, USA, 2013.

[36] B. D. Gillborn, "Education policy as an act of white supremacy: whiteness, critical race theory and education reform," Journal of Education Policy, vol. 20, no. 4, pp. 485-505, 2005.

[37] Z. Leonardo, Race, Whiteness, and Education, Routledge, New York, NY, USA, 2009.

[38] D. G. Solorozano and T. J. Yosso, "Critical race methodology: counter storytelling as an analytical framework for education research," Qualitative Inquiry, vol. 8, no. 1, pp. 23-44, 2002.
[39] W. F. Tate IV, "Critical race theory and education: history, theory, and implications," Review of Research in Education, vol. 22, pp. 195-247, 1997.

[40] A. D. Dixson and C. K. Rousseau, "And we are still not saved: critical race theory in education," in Critical Race Theory in Education: All God's Children Got a Song, A. D. Dixson and C. K. Rousseau, Eds., pp. 31-56, Routledge, New York, NY, USA, 2006.

[41] M. M. Zamudio, C. Russell, F. A. Rios, and J. L. Bridgeman, Critical Race Theory Matters: Education and Ideology, Routledge, New York, NY, USA, 2011.

[42] E. Bonilla-Silva, White Supremacy and Racism in the Post Civil Rights Era, Lynne Rienner Publishers, Boulder, Colo, USA, 2001.

[43] E. Bonilla-Silva, Racism without Racists: Color-Blind Racism and the Persistence of Racial Inequality in the United States, Rowman \& Littlefield, Lanham, Md, USA, 2006.

[44] D. Ritchie, Doing Oral History, Oxford University Press, New York, NY, USA, 2003.

[45] P. Thompson, The Voice of the Past: Oral History, Oxford Press, New York, NY, USA, 2000.

[46] V. J. Janesick, "Oral history as a social justice project: issues for the qualitative researcher," The Qualitative Report, vol. 12, no. 1, pp. 111-121, 2007.

[47] J. U. Ogbu and H. D. Simons, "Voluntary and involuntary minorities: a cultural-ecological theory of school performance with some implications for education," Anthropology and Education Quarterly, vol. 29, no. 2, pp. 155-188, 1998.

[48] S. Merriam, Qualitative Research and Case Study Applications in Education, Jossey-Bass, San Francisco, Calif, USA, 1998.

[49] W. Strauss and N. Howe, Generations: The History of America's Future, 1584 to 2069, Morrow, New York, NY, USA, 1991.

[50] United States Census Bureau, Urban and Rural Classification, United States Census Bureau, Washington, DC, USA, 2013.

[51] J. Kuscera, New York State's Extreme School Segregation: Inequality, Inaction and a Damaged Future, The Civil Rights Project, New York, NY, USA, 2014.

[52] J. W. Creswell, Research Design: Qualitative, Quantitative and Mixed Methods Approaches, Sage Publications, Thousand Oaks, Calif, USA, 2003.

[53] R. S. Jones, V. Torres, and J. Arminio, Negotiating the Complexities of Qualitative Research in Higher Education: Fundamental Elements and Issues, Taylor \& Francis, New York, NY, USA, 2006.

[54] L. Tillman, "Culturally sensitive research approaches: an African American perspective," Educational Researcher, vol. 31, no. 9, pp. 3-12, 2002.

[55] S. Hatchett and H. Schuman, "White respondents and race of interviewer effects," Public Opinion Quarterly, vol. 39, pp. 523$528,1975$.

[56] S. Nieto, "Lessons from students on creating a chance to dream," Harvard Educational Review, vol. 64, no. 4, pp. 392-426, 1994.

[57] H. R. Milner, "Race, culture, and researcher positionality: Working through dangers seen, unseen, and unforeseen," Educational Researcher, vol. 36, no. 7, pp. 388-400, 2007.

[58] B. G. Glaser and A. L. Strauss, The Discovery of Grounded Theory: Strategies for Qualitative Research, Aldine, Chicago, Ill, USA, 1967. 
[59] Y. S. Lincoln and E. G. Guba, "Paradigmatic controversies, contradictions, and emerging confluences," in Handbook of Qualitative Research, N. K. Denzin and Y. S. Lincoln, Eds., pp. 163-188, Sage, Thousand Oaks, Calif, USA, 2nd edition, 1985.

[60] S. Fordham, "Racelessness as a factor in Black students' school success: pragmatic strategy or Pyrrhic victory ?" Harvard Educational Review, vol. 58, no. 1, pp. 54-84, 1988.

[61] J. Garland and N. Chakraborti, "Race, space and placeexamining identity and cultures of exclusion in rural England," Ethnicities, vol. 6, no. 2, pp. 159-177, 2006.

[62] D. Bell, "The interest-convergence dilemma and brown v. board of education," The Harvard Law Review, vol. 93, pp. 518-533, 1980.

[63] G. López, "The (racially neutral) politics of education: a critical race theory perspective," Educational Administration Quarterly, vol. 39, no. 1, pp. 68-94, 2003.

[64] K. Alexander, D. Entwisle, and M. Thompson, "School perfomance, status relations and the stucture of sentiment: bringing the teacher back in," American Sociological Review, vol. 55, pp. 665-682, 1987.

[65] C. J. Cohen, Democracy Remixed: Black Youth and the Future of American Politics, Oxford Press, New York, NY, USA, 2010.

[66] D. B. Downey and S. Pribesh, "When race matters: teachers' evaluations of students' classroom behavior," The Sociology of Education, vol. 77, no. 4, pp. 267-282, 2004.

[67] R. F. Ferguson, "Teachers' perceptions and expectations and the Black-White test score gap," Urban Education, vol. 38, no. 4, pp. 460-507, 2003.

[68] T. Zuberi and E. Bonilla-Silva, White Logic, White Methods, Rowman \& Littlefield, Lanham, Md, USA, 2008.

[69] D. L. Brown and K. A. Schafft, Rural People and Communities in the 21st Century: Resilience and Transformation, Polity Press, Malden, Mass, USA, 2011.

[70] E. Patten, "The black-white and urban rural divides in perceptions of racial fairness," in Pew Research Center, 2013, http:// www.pewresearch.org/fact-tank/2013/08/28/the-black-whiteand-urban-rural-divides-in-perceptions-of-racial-fairness/.

[71] B. D. Tatum, Why Are All the Black Kids Sitting Together in the Cafeteria? And Other Conversations about Race, Basic Books, New York, NY, USA, 1997.

[72] D. Sue, Microaggressions in Everyday Life: Race, Gender and Sexual Orientation, John Wile \& Sons, Hoboken, NJ, USA, 2010.

[73] G. Ladson-Billings and W. Tate, "Toward a critical race theory of education," Teachers College Record, vol. 97, no. 1, pp. 47-68, 1995.

[74] J. D. Anderson, The Education of Blacks in the South, 1860-1935, University of North Carolina Press, Chapel Hill, NC, USA, 1988. 

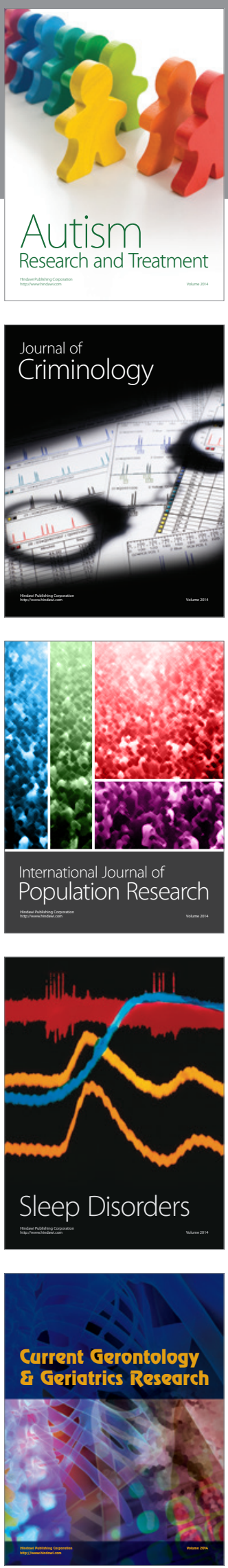
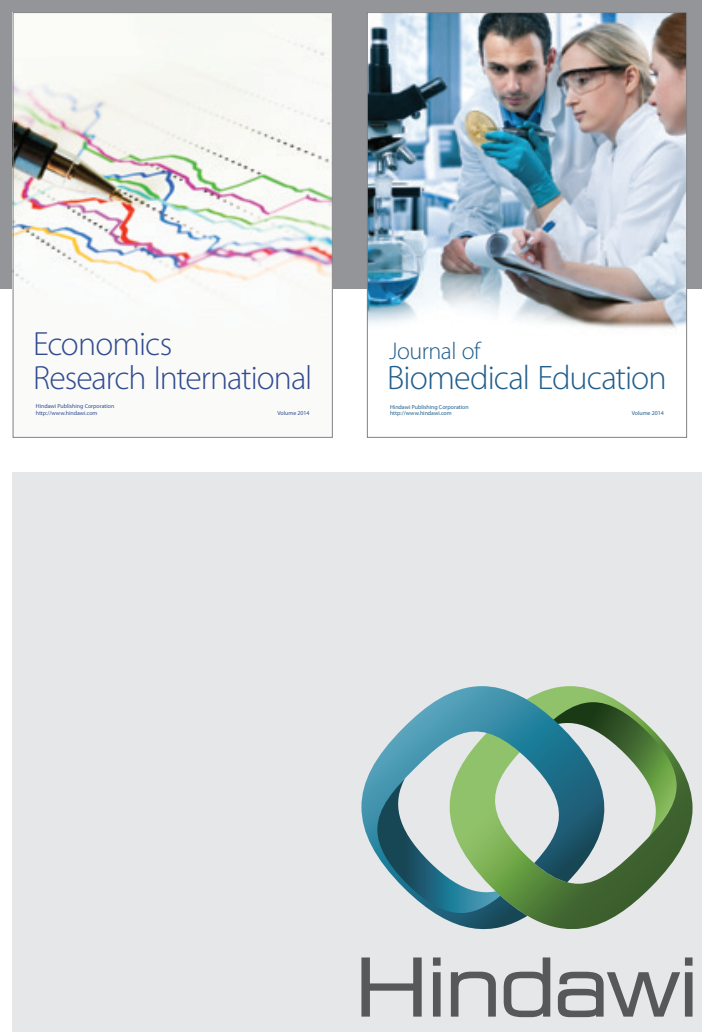

Submit your manuscripts at

http://www.hindawi.com
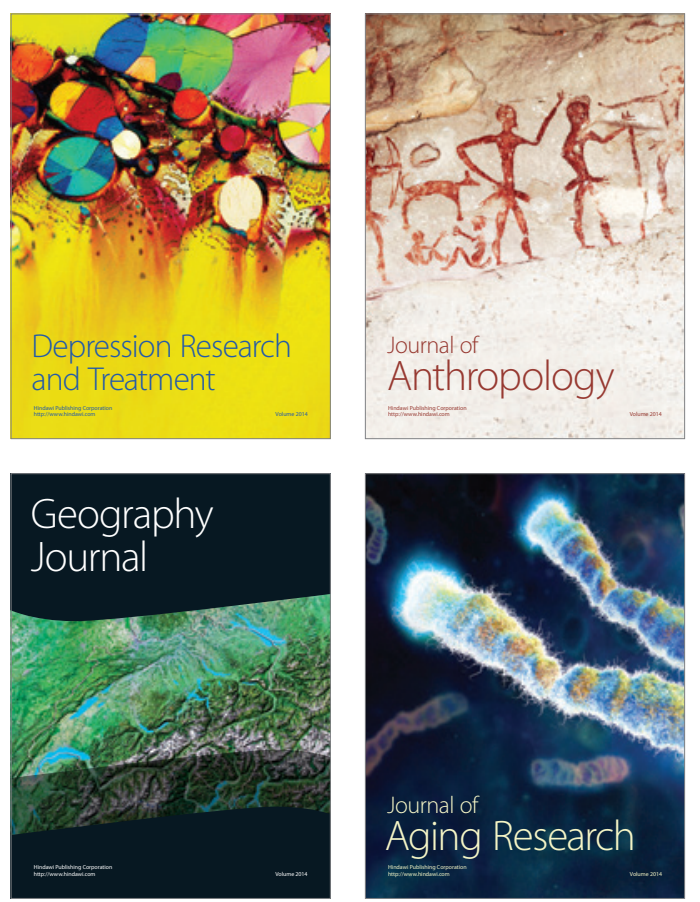
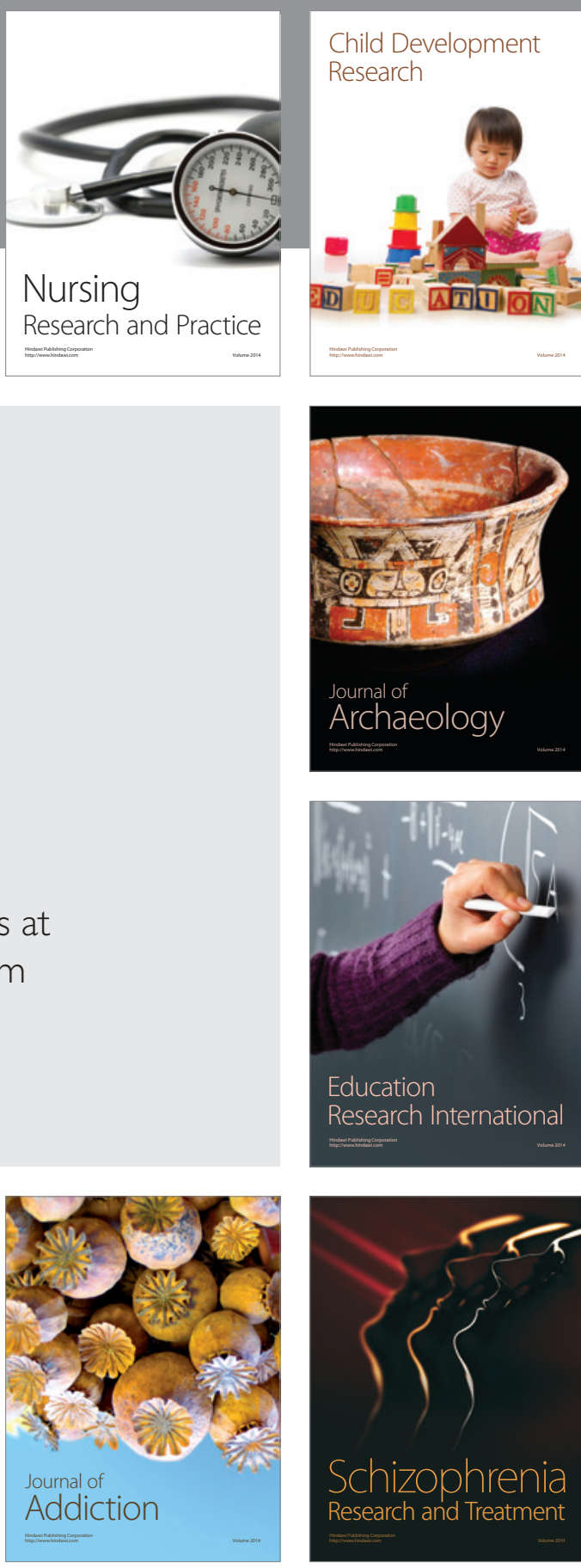

(D)
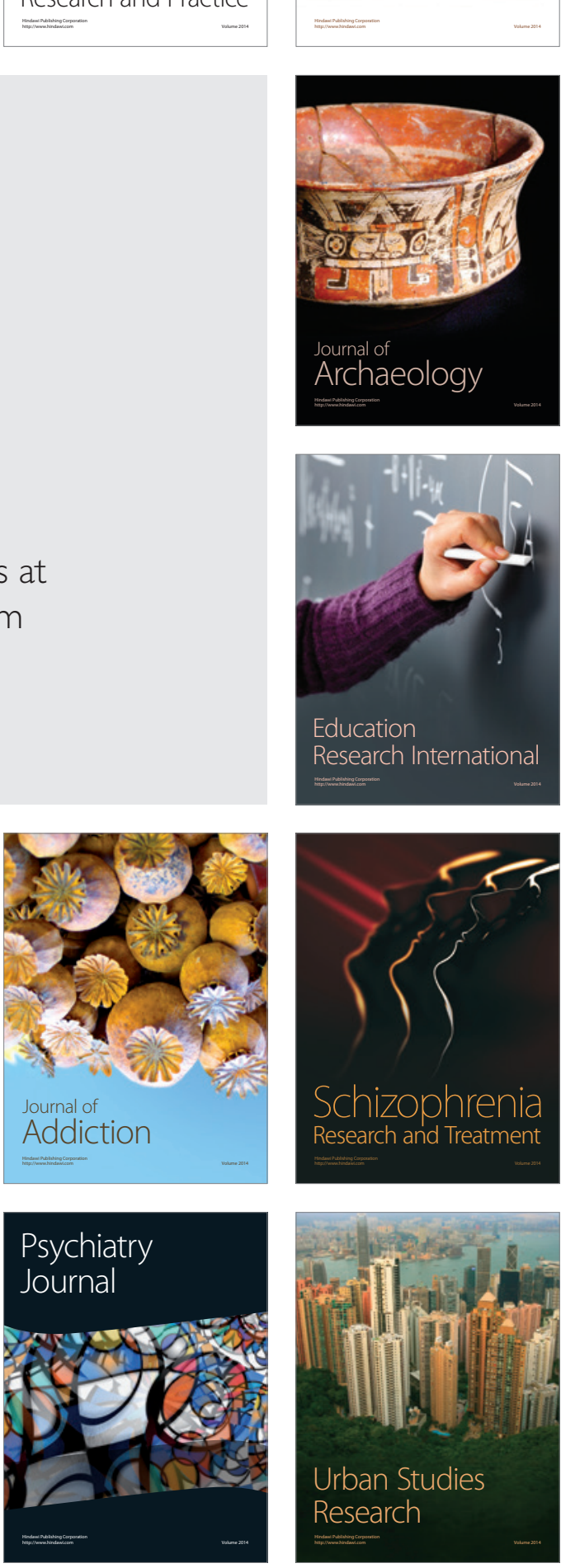